\title{
Regulation of Blood Flow in Paget's Disease of Bone
}

\author{
Donald D. Heistad, Francois M. Abboud, Phillip G. Schmm, \\ ALLYN L. MARK, and WIILIAM R. WIISON \\ From the Cardiovascular and Clinical Pharmacology Divisions, Department of \\ Internal Medicine, University of Iowa College of Medicine and Veterans \\ Administration Hospital, Iowa City, Iowa 52242
}

\begin{abstract}
A B S T RACT Previous studies have demonstrated an increase in blood flow to extremities involved by Paget's disease of bone. It has been assumed that the increase in blood flow is through bone, but warmth of skin overlying Pagetic bone suggests that cutaneous blood flow might be increased. In three patients with Paget's disease involving one extremity, we compared blood flow in "Pagetic" extremities with flow in the contralateral normal extremities. Resting blood flow (measured with water plethysmographs) was $14.2 \pm 2.9$ (mean $\pm \mathrm{SE}$ ) $\mathrm{ml} / \mathrm{min} \times 100 \mathrm{ml}$ extremity in the Pagetic limbs and $2.5 \pm 0.7 \mathrm{ml} / \mathrm{min}$ in the contralateral normal limbs. The contribution of cutaneous flow to the increase in extremity blood flow was evaluated with epinephrine iontophoresis, which suppresses flow to skin but not to underlying tissue. Epinephrine iontophoresis of the Pagetic extremities decreased blood flow from $14.2 \pm 2.9$ to $3.6 \pm 1.5 \mathrm{ml} / \mathrm{min}$.
\end{abstract}

Local heating (which increases cutaneous flow only) failed to increase blood flow in the Pagetic extremities as much as it did in the normal extremities. This suggests that cutaneous vessels in the Pagetic extremities were already dilated. During heating, blood flow in the normal extremities was similar to resting flow in the Pagetic extremities; this indicates that increases in cutaneous flow could account for most of the increase in total blood flow in the Pagetic extremities.

Adrenergic control of blood flow to the Pagetic extremities was compared with that of the normal extremities. Vasoconstrictor responses to reflex stimuli in the Pagetic extremities were reduced; when vasoconstriction occurred it was gradual and sustained

This work was presented in part at the Midwest Section of the American Federation for Clinical Research, Chicago, IIl., November, 1972. A preliminary report has appeared in abstract form (1).

Received for publication 9 January 1973 and in revised form 9 August 1974. after termination of the stimuli, which suggests an exaggerated humoral response but reduced neural response to the stimuli. Intravenous epinephrine produced vasoconstriction in the Pagetic extremities and vasodilatation in the normal extremities.

In summary, responses to epinephrine iontophoresis and heating suggest that the increase in blood flow in Pagetic extremities is primarily the result of cutaneous vasodilatation.

\section{INTRODUCTION}

Blood flow to extremities involved by Paget's disease of bone may be increased to nine times normal values (2). It has been suggested that the increase in blood flow can be explained by arteriovenous fistulas in bone (3), since the oxygen tension in venous blood from "Pagetic" extremities is elevated (2). Although there is proliferation of vessels in bones with Paget's disease (2), neither histologic studies (3), arteriograms (4), nor injection of isotope-labeled microspheres (5) has demonstrated arteriovenous fistulas.

In the present study we attempted to clarify the mechanism for the increased blood flow to extremities in patients with Paget's disease. Warmth of skin over Pagetic bone suggested that cutaneous blood flow might be increased. Blood flow to skin of the abnormal extremities was suppressed by epinephrine iontophoresis to determine the extent to which the increase in blood flow to extremities involved by Paget's disease is the result of increased cutaneous blood flow.

Responses to local heating of the extremities were also measured. Heating increases blood flow in cutaneous vessels (6). If cutaneous vessels in the Pagetic extremities are dilated, the increase in blood flow in the Pagetic limbs would be expected to be less than normal.

Finally, adrenergic control of blood flow to the extremities involved by Paget's disease was compared 
TABLE I

Clinical Data in Patients with Paget's Disease

\begin{tabular}{|c|c|c|c|c|c|}
\hline Patient & Age & Sex & Radiographic findings & Alkaline phosphatase & $\begin{array}{l}\text { Extremity } \\
\text { studied }\end{array}$ \\
\hline C. F. & 61 & M & $\begin{array}{l}\text { Cortical irregularity, sclerosis, and bowing of radius } \\
\text { typical of Paget's disease; contralateral arm normal. }\end{array}$ & $\begin{array}{l}60 \mathrm{mU} / \mathrm{ml} \text { (normal } \\
30-85 \mathrm{mU} / \mathrm{ml}, \mathrm{IU} \text { ) }\end{array}$ & Forearm \\
\hline J.S. & 63 & M & $\begin{array}{l}\text { Patchy densities and radiolucency with separation } \\
\text { of tables of skull and basilar invagination; } \\
\text { cortical irregularity and patchy radiolucency of } \\
\text { tibia; contralateral leg normal. }\end{array}$ & $\begin{array}{c}>305 \mathrm{mU} / \mathrm{ml} \text { (normal } \\
30-85 \mathrm{mU} / \mathrm{ml}, \mathrm{IU})\end{array}$ & Calf \\
\hline H. W. & 53 & M & $\begin{array}{l}\text { Cortical irregularity and patchy changes of femur, } \\
\text { with old fracture; cortical expansion and } \\
\text { irregularity of tibia, with coarse trabecular } \\
\text { markings; contralateral calf normal. }\end{array}$ & $\begin{array}{l}6.1 \text { (normal } 0.8-3.0 \\
\text { Bessey Lowrey U) }\end{array}$ & Calf \\
\hline
\end{tabular}

with that of the normal extremities. Vascular responses to reflex and humoral stimuli were examined.

\section{METHODS}

Three patients with Paget's disease were studied (Table I). Each had typical radiographic findings of Paget's disease of an extremity, with a radiographically normal contralateral extremity. One patient had a normal serum alkaline phosphatase, perhaps because the skeletal involvement was limited.

Three experiments were done on each patient. The studies were done with the patient supine in a warm room. Skin temperature was measured over the Pagetic bone and at a comparable location on the contralateral extremity, using thermistor probes. Blood flow was measured with water plethysmographs (7). Forearm blood flow was measured in both arms in one patient and calf blood flow was measured in both legs in two patients. A plethysmograph was placed around the extremity over the area of bony involvement (as indicated by $\mathrm{X}$ ray), and another plethysmograph was placed at a corresponding location on the contralateral normal extremity. Pneumatic cuffs placed distal to the plethysmographs were inflated to suprasystolic pressures during the measurements to exclude the contribution of venous return from the hand or foot to changes in volume of the forearm. Pneumatic cuffs were also placed proximal to the plethysmographs and inflated intermittently for 6-10 s at pressures sufficient to produce venous occlusion. Blood flow to the forearm or calf was calculated from the rate of increase in volume of the forearm or calf during venous occlusion and expressed in $\mathrm{ml} / \mathrm{min} \times 100 \mathrm{ml}$ of extremity.

In the first experiment on each patient, resting measurements of extremity blood flow were obtained. The plethysmographs were then removed, and epinephrine iontophoresis was performed on the Pagetic extremity by the technique of Collins and Ludbrook (8). The extremity was cleaned, shaved, and washed with acetone. The extremity was wrapped in gauze soaked with epinephrine hydrochloride $1: 2,000$ ( $\mathrm{pH} 4.5$ ), covered by aluminum foil, and wrapped with an elastic bandage. Another extremity was similarly wrapped, but saline was used rather than epinephrine. The Pagetic extremity served as the anode and the other extremity as the cathode. Iontophoresis at a current of $20 \mathrm{~mA}$ was maintained for $20 \mathrm{~min}$. Iontophoresis has been shown to cause nearly complete suppression of blood flow to the skin (9) and in these patients caused blanching of the Pagetic extremity. There was no evidence of systemic absorption of epinephrine during the procedure, as blood flow in the normal extremity and heart rate did not increase. After epinephrine iontophoresis, water plethysmographs were placed at the same location around both extremities, and blood flow was again measured.

In the second experiment, the response to local heating was observed. Blood flow in the normal and Pagetic extremities was measured first when the temperature of the water in the plethysmographs was $32.5^{\circ} \mathrm{C}$. Then the water in the plethysmographs was warmed to $44^{\circ} \mathrm{C}$ for $20-30 \mathrm{~min}$, and blood flow was again measured.

In one patient (C. F.), bradykinin activity in blood from the normal and Pagetic arms was assayed to determine whether release of bradykinin by Pagetic bone might account for cutaneous vasodilatation. Venous blood samples from each antecubital fossa were drawn into syringes containing $0.4 \mathrm{~N}$ perchloric acid and assayed by a modification (10) of the method of Webster and Gilmore.

In the third experiment responses to reflex vasoconstrictor stimuli and to an intravenous infusion of epinephrine were measured. Blood flow in the normal and Pagetic extremities was measured. Arterial pressure was measured by auscultation in J. S. and $\mathrm{H}$. W. and with a polyethylene cannula (PE 60) in the brachial artery in C. F. Responses to reflex stimuli were observed by measuring the response to lower body negative pressure (11) in C. F. and to application of ice to the forehead in all three patients. Responses to lower body negative pressure could not be measured in the two patients in whom calf blood flow was measured. The response to a humoral stimulus was evaluated in C. F. and J. S. by infusing epinephrine hydrochloride intravenously at 5 and $10 \mu \mathrm{g} / \mathrm{min}$.

Because the results indicated that resting blood flow was increased and vasoconstrictor responses to reflex stimuli were impaired in the Pagetic extremities, we considered the possibility that there might be interruption of the sympathetic nerves in the Pagetic extremities. If this were the case, one would expect impaired reflex responsiveness of vessels distal to the site of Paget's disease. To test this possibility we measured finger blood flow in C. F. An air plethysmograph was placed on the middle finger on the Pagetic and normal sides. Changes in volume of the finger were measured during venous occlusion. Congesting pneu- 
matic cuffs were placed around the finger proximal to the plethysmographs and inflated intermittently for 6-10 s to a pressure sufficient to produce venous occlusion (about 40 $\mathrm{mm} \mathrm{Hg}$ ). Blood flow in the fingers was measured at rest and during a deep breath, which is a potent reflex vasoconstrictor stimulus.

\section{RESULTS}

Skin temperature and resting blood flow. Skin temperature and blood flow were higher in the Pagetic than in the normal extremities. Skin temperatures on the normal and abnormal sides were $33.6^{\circ}$ and $35.2^{\circ} \mathrm{C}$, respectively, in C. F.; $32.8^{\circ}$ and $34.9^{\circ} \mathrm{C}$ in J. S.; and $32.8^{\circ}$ and $33.8^{\circ} \mathrm{C}$ in $\mathrm{H}$. W. Before epinephrine iontophoresis, resting blood flow averaged $2.5 \pm 0.7$ (mean $\pm \mathrm{SE}$ ) $\mathrm{ml} / \mathrm{min} \times 100 \mathrm{ml}$ extremity in the normal limbs and $14.2 \pm 2.9 \mathrm{ml} / \mathrm{min}$ in the Pagetic limbs.

Response to epinephrine iontophoresis. Suppression of blood flow to the skin by epinephrine iontophoresis decreased blood flow in the Pagetic extremities from
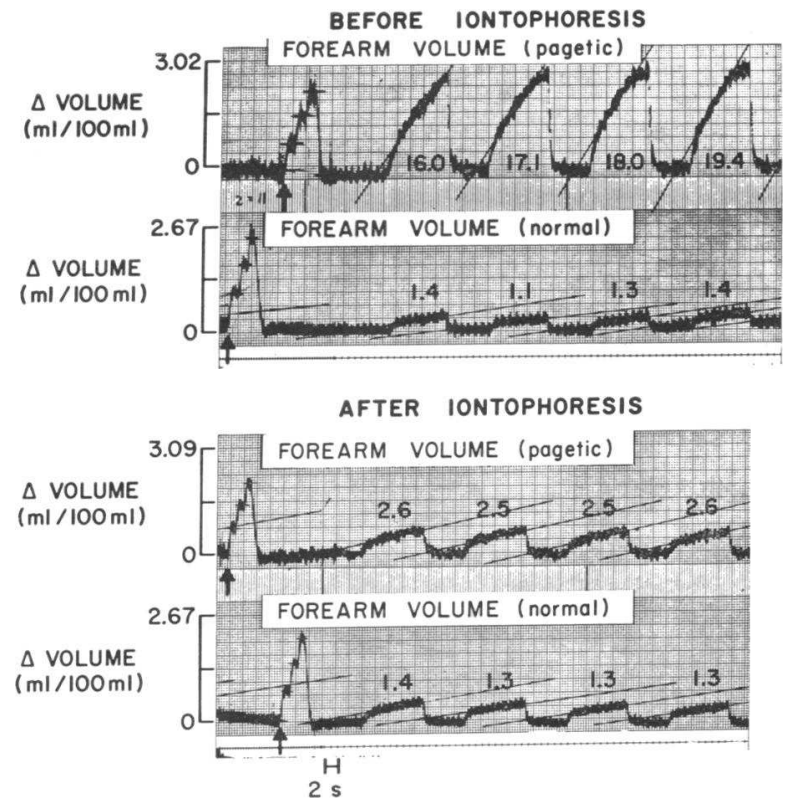

FIgURe 1 Changes in volume in Pagetic and normal forearms of patient C. F. before and after epinephrine iontophoresis of the Pagetic forearm. The slopes of the increase in forearm volume during venous occlusion were used to calculate blood flow to the forearm in $\mathrm{ml} / \mathrm{min} \times 100 \mathrm{ml}$ of forearm, as indicated by the numbers below or above the slopes. Calibrations of the plethysmographs are indicated by the arrows. Addition of $2-\mathrm{ml}$ increments of water to the plethysmographs caused similar deflections, indicating comparable sensitivity of the plethysmographs on both arms before and after epinephrine iontophoresis. Iontophoresis caused a sevenfold decrease in flow in the Pagetic forearm, indicating that most of the blood flow to the Pagetic forearm is cutaneous.
TABLE II

Effect on Blood Fiow of Epinephrine Iontophoresis Performed on Pagetic Extremities

\begin{tabular}{|c|c|c|c|c|}
\hline \multirow[b]{3}{*}{ Patient } & \multicolumn{2}{|c|}{ Normal extremity } & & \\
\hline & \multirow[b]{2}{*}{$\begin{array}{l}\text { Control } \\
\text { state }\end{array}$} & \multirow{2}{*}{$\begin{array}{c}\text { After } \\
\text { ionto- } \\
\text { phoresis } \\
\text { of Pagetic } \\
\text { side }\end{array}$} & \multicolumn{2}{|c|}{ Pagetic extremity } \\
\hline & & & $\begin{array}{l}\text { Control } \\
\text { state }\end{array}$ & $\begin{array}{l}\text { After } \\
\text { ionto- } \\
\text { phoresis }\end{array}$ \\
\hline & \multicolumn{2}{|c|}{$\mathrm{ml} / \mathrm{min} \times 100 \mathrm{ml}$ extremity } & \multicolumn{2}{|c|}{$\mathrm{ml} / \mathrm{min} \times 100 \mathrm{ml}$ extremity } \\
\hline C. F. & 1.3 & 1.3 & 18.0 & 2.6 \\
\hline J. S. & 2.6 & 2.2 & 16.1 & 6.6 \\
\hline H. W. & 3.6 & 3.3 & 8.5 & 1.5 \\
\hline Mean & 2.5 & 2.3 & 14.2 & 3.6 \\
\hline $\mathrm{SE}$ & \pm 0.7 & \pm 0.6 & \pm 2.9 & \pm 1.5 \\
\hline
\end{tabular}

$14.2 \pm 2.9$ to $3.6 \pm 1.5$ (Fig. 1, Table II). Blood flow in the normal extremities which were not iontophoresed did not increase, which suggests that there was minimal systemic absorption of epinephrine.

Response to heating. Local heating of both extremities increased blood flow by $8.3 \pm 3.0 \mathrm{ml} / \mathrm{min}$ in the normal extremities and only $3.3 \pm 1.7 \mathrm{ml} / \mathrm{min}$ in the Pagetic extremities (Fig. 2, Table III). Blood flow in the normal extremities during heating was similar to resting flow in the Pagetic extremities.

Bradykinin activity. There was no detectable bradykinin activity in the venous blood of either arm in patient C. F.

Responses to vasoconstrictor stimuli. Lower body negative pressure decreased blood flow in both forearms in patient C. F. (Fig. 3). Maximal vasoconstriction was achieved more rapidly in the normal arm than in the Pagetic arm. After release of lower body negative pressure, blood flow was restored promptly and exceeded control values in the normal forearm but vasoconstriction was maintained in the abnormal forearm. Vasoconstrictor responses to application of ice to the forehead were minimal in the Pagetic extremities (Fig. 4). Mild vasoconstriction occurred in C. F. but the vasoconstriction was sustained after the ice was removed. During infusion of epinephrine, there was vasodilatation in the normal extremities and vasoconstriction in the abnormal extremities (Fig. 5).

Reflex vasoconstrictor responses distal to the site of Paget's disease were preserved in C. F. On the normal side, finger blood flow was $8.0 \pm 0.8 \mathrm{ml} / \mathrm{min} \times 100$ $\mathrm{ml}$ finger at rest and $2.9 \pm 1.0 \mathrm{ml} / \mathrm{min}$ during a deep breath. On the Pagetic side, finger blood flow was $9.3 \pm 1.0 \mathrm{ml} / \mathrm{min}$ at rest and $1.0 \pm 1.0 \mathrm{ml} / \mathrm{min}$ during a deep breath. 


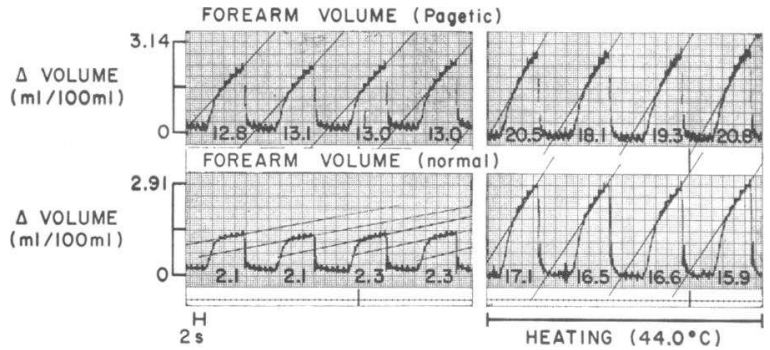

Figure 2 Effect of local heating in patient C. F. The left panel is a record of forearm blood flow before heating the forearms and the right panel indicates the responses to warming the water in both plethysmographs to $44^{\circ} \mathrm{C}$.

\section{DISCUSSION}

Previous studies have demonstrated an increase in blood flow to extremities involved with Paget's disease and it has been assumed that the increase in flow is entirely through bone $(2,3)$. The warmth of the skin overlying the "Pagetic" bone, noted in our patients and in other studies (2), suggested that cutaneous blood flow might contribute significantly to the increase in extremity flow. The major finding in this study was the profound decrease in blood flow to the Pagetic extremities after epinephrine iontophoresis, which indicates that most of the increase in blood flow in the extremities with Paget's disease was the result of increased cutaneous blood flow.

We considered the possibility that absorption of epinephrine during iontophoresis might allow epinephrine to enter the systemic circulation and decrease extremity blood flow by constricting vessels to bone (12). This possibility is excluded by the absence of systemic effects of epinephrine, as blood flow in the contralateral extremities and heart rate did not increase during the period of measurements after iontophoresis. It is also unlikely that epinephrine penetrated the skin and muscle to constrict vessels to bone during iontophoresis, since a previous study indicated that epinephrine iontophore-

TABLE III

Effect of Local Heating on Blood Flow

\begin{tabular}{|c|c|c|c|c|c|c|}
\hline \multirow[b]{2}{*}{ Patient } & \multicolumn{3}{|c|}{ Normal extremity } & \multicolumn{3}{|c|}{ Pagetic extremity } \\
\hline & $\begin{array}{c}\text { Control } \\
\text { state }\end{array}$ & $\begin{array}{l}\text { During } \\
\text { heating }\end{array}$ & $\begin{array}{l}\text { Increase } \\
\text { during } \\
\text { heating }\end{array}$ & $\begin{array}{l}\text { Control } \\
\text { state }\end{array}$ & $\begin{array}{l}\text { During } \\
\text { heating }\end{array}$ & $\begin{array}{c}\text { Increase } \\
\text { during } \\
\text { heating }\end{array}$ \\
\hline & \multicolumn{3}{|c|}{$\mathrm{ml} / \mathrm{min} \times 100 \mathrm{ml}$ extremity } & \multicolumn{3}{|c|}{$\mathrm{ml} / \mathrm{min} \times 100 \mathrm{ml}$ extremity } \\
\hline C. F. & 2.2 & 16.5 & +14.3 & 13.0 & 19.7 & +6.7 \\
\hline J. S. & 1.5 & 7.1 & +5.6 & 11.5 & 12.7 & +1.2 \\
\hline H. W. & 2.7 & 7.6 & +4.9 & 7.3 & 9.3 & +2.0 \\
\hline Mean & 2.1 & 10.4 & +8.3 & 10.6 & 13.9 & +3.3 \\
\hline $\mathrm{SE}$ & \pm 0.4 & \pm 3.0 & \pm 3.0 & \pm 1.7 & \pm 3.1 & \pm 1.7 \\
\hline
\end{tabular}

sis suppresses cutaneous blood flow but does not penetrate subcutaneous tissue or muscle (9).

It seemed possible that bradykinin, a potent vasodilator substance, might be released locally and dilate cutaneous vessels. However, bradykinin was not found in the venous blood from the Pagetic arm in one patient. We would like to suggest the possibility that excessive heat production from increased metabolic activity of the Pagetic bone might cause vasodilatation in the skin. Heating causes vasodilatation in skin but not muscle (6) so we would not expect excessive heat production in bone to dilate vessels in muscle.

The increase in blood flow in skin overlying Pagetic bone could be the result of either proliferation of vessels in the skin or of dilatation of preexisting vessels. We are not aware of histologic evidence which relates to either of these possibilities, but the present study provides indirect evidence which favors the latter possibility. The smaller increase in blood flow in the Pagetic extremities than in the normal extremities during heating suggests that the cutaneous vessels in the Pagetic extremities were already dilated and thus supports the concept of vasodilatation in skin overlying Pagetic bone. During heating, blood flow in the normal extremities was similar to resting flow in the Pagetic extremities. This indicates that dilatation of normal cutaneous vessels could account for most of the increase in total blood flow in the Pagetic extremities.

There is close proximity between skin and underlying bone in the forearm and calf, which may contribute to the pronounced increase in cutaneous flow when Paget's disease involves the extremities. It is likely that increases in cutaneous flow would not be as great in parts of the body where the skin is separated from bone by a thick layer of muscle.



FIgURE 3 Values for forearm blood flow during lower body negative pressure in patient C. F. Each point is the average of two consecutive measurements. 
The major finding of this study was the increase in cutaneous blood flow in the Pagetic extremities, but we also should mention the studies of vascular responsiveness. The vasoconstrictor response to intravenous epinephrine in the Pagetic extremities contrasts with the vasodilator response in the normal extremities. The normal limb vascular response to epinephrine is dilatation (13) since flow to muscle predominates and epinephrine causes vasodilatation in muscle. The normal response to epinephrine in blood vessels in skin and bone is constriction $(12,13)$. Thus the vasoconstrictor response to intravenous epinephrine in the Pagetic extremities reflects the predominance of blood flow to skin and bone.

Although the abnormal extremities demonstrated vasoconstrictor responses to lower body negative pressure and ice on the forehead, the constriction appeared delayed (compared with the normal extremities) and was sustained after removal of the stimuli, suggesting a major humoral rather than neurogenic component in the vasoconstrictor response. It is possible that neurogenic responses are reduced in the cutaneous vessels of the Pagetic extremities because of the local increase in temperature (14). The increase in resting cutaneous blood flow and impairment of reflex vasoconstrictor responses in the Pagetic extremities raised the possibility that sympathetic nerves to the skin might be interrupted in the Pagetic limbs. Because reflex responses were preserved in the finger, distal to the site of Paget's disease, this possibility is unlikely.

This study provides no direct evidence concerning blood flow to bone in Paget's disease. Previous studies $(4,5)$ indicate that bone flow is increased in Paget's disease, but quantitative estimates of the increase in
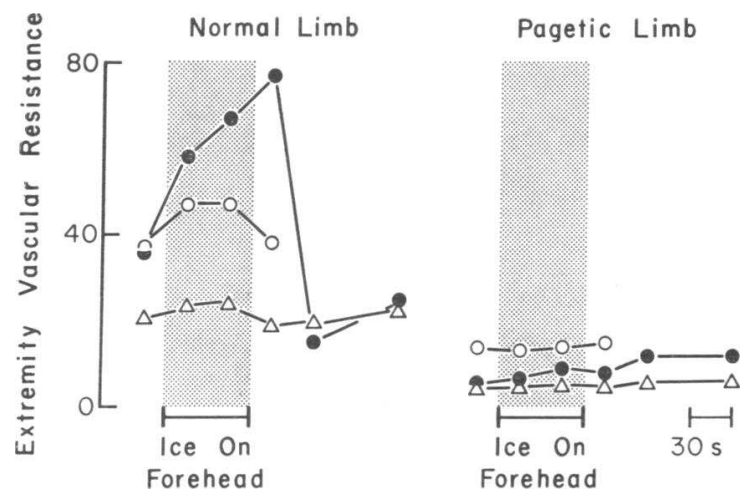

FIGURE 4 Extremity vascular resistance during the application of ice to the forehead. Each point is the average of values obtained during $30 \mathrm{~s}$. The symbols used for the three patients are C. F. $(\bullet)$, J. S. $(\triangle)$, and H. W. (O). Values for vascular resistance, rather than blood flow, are presented in this graph because there was a significant increase in arterial pressure during ice on the forehead.

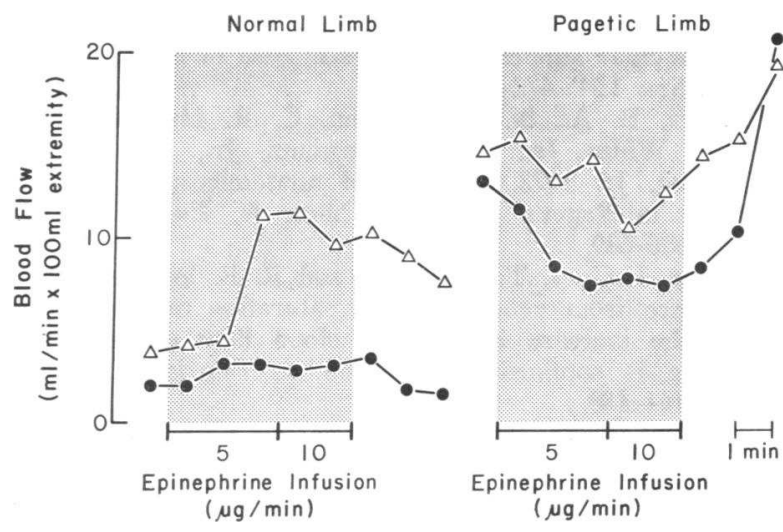

FIGURE 5 Intravenous infusion of two doses of epinephrine increased blood flow in the normal extremities and decreased flow in the Pagetic extremities of two patients. Each point represents the average of values obtained during $1 \mathrm{~min}$.

flow to bone have not been reported. We suggest that there probably is a modest increase in blood flow to bone in Paget's disease (as indicated by previous studies), but that most of the increase in blood flow to extremities is the result of cutaneous vasodilatation.

The elevated oxygen tension in venous blood from Pagetic extremities (2) could be the result of arteriovenous fistulas in bone (3). However, several studies utilizing different techniques have failed to demonstrate arteriovenous fistulas (3-5). The present study may provide an alternative explanation for the elevated venous oxygen tension in Paget's disease. Venous blood from cutaneous vascular beds has a high oxygen tension (6), so the elevated oxygen tension in venous blood from Pagetic extremities may be the result of the increase in cutaneous blood flow.

\section{ACKNOWLEDGMENTS}

We wish to thank Doctors Kenneth Melmon and Henry Bourne for assaying the blood samples for bradykinin activity.

This study was supported by Clinical Investigatorships from the Veterans Administration, by research grants HL 16149, HL 02644, and HL 16066 and Program Project Grant HL 14388 from the National Heart and Lung Institute, and grant MO 1-FR-59 to the Clinical Research Center.

\section{REFERENCES}

1. Heistad, D. D., F. M. Abboud, P. G. Schmid, A. L. Mark, and W. R. Wilson. 1972. Regulation of blood flow in Paget's disease of bone. Clin. Res. 20: 718. (Abstr.)

2. Edholm, O. G., and S. Howarth. 1953. Studies on the peripheral circulation in osteitis deformans. Clin. Sci. (Oxf.). 12: 277-285.

3. de Deuxchaisnes, C. N., and S. M. Krane. 1964. Paget's disease of bone: Clinical and metabolic observations. Medicine (Baltimore). 43 : 233-266. 
4. Storsteen, K. A., and J. M. Jones. 1954. Arteriography and vascular studies in Pagets's disease of bone. J. Am. Med. Soc. 154 : $472-474$

5. Rhodes, B. A., N. D. Greyson, C. R. Hamilton, Jr., R. I. White, Jr., F. A. Giargiana, Jr., and H. M. Wagner, Jr. 1972. Absence of anatomic arteriovenous shunts in Paget's disease of bone. N. Engl. J. Med. 287 : 686-689.

6. Roddie, I. C., J. T. Shepherd, and R. F. Whelan. 1956. Evidence from venous oxygen saturation measurements that the increase in forearm blood flow during body heating is confined to the skin. J. Physiol. (Lond.). 134: 444-450.

7. Wilkins, R. W., and L. W. Eichna. 1941. Blood flow to the forearm and calf. Vascomotor reactions; role of sympathetic nervous system. Johns Hopkins Med. J. 68: 425-449.

8. Collins, G. M., and J. Ludbrook. 1967. Behavior of vascular beds in the human upper limb at low perfusion pressure. Circ. Res. 21: 319-325.

9. Cooper, K. E., O. G. Edholm, and R. F. Mottram.
1955. The blood flow in skin and muscle of human forearm. J. Physiol. (Lond.). 128: 258-267.

10. Nies, A. S., R. P. Forsyth, H. E. Williams, and K. L. Melmon. 1968. Contribution of kinins to endotoxin shock in unanesthetized rhesus monkeys. Circ. Res. 22: 155-164.

11. Brown, E., J. S. Goei, A. D. M. Greenfield, and G. C. Plassaras. 1966. Circulatory responses to simulated gravitational shifts of blood in man induced by exposure of the body below the iliac crests to sub-atmospheric pressure. J. Physiol. (Lond.). 183: 607-627.

12. Stein, A. M., Jr., and N. B. White. 1966. The effect of adrenalin on the blood flow to a long bone. Surg. Gynecol. Obst. 123: 55-58.

13. Green, H. D., and J. H. Kepchar. 1959. Control of peripheral resistance in major systemic vascular beds. Physiol. Rev. 39: 617-686.

14. Sams, W. M., Jr., and R. K. Winkelmann. 1969. Temperature effects on isolated resistance vessels of skin and mesentery. Am. J. Physiol. 216: 112-116. 